\title{
PERAN SISTEM VOLUNTEERED GEOGRAPHIC INFORMATION (VGI) SISTEM DALAM PENGURANGAN RISIKO BENCANA: KONSEP DAN IMPLEMENTASI
}

\section{THE ROLE OF VOLUNTEERED GEOGRAPHIC INFORMATION (VGI) SYSTEM IN DISASTER RISK REDUCTION: CONCEPT AND IMPLEMENTATION}

\author{
Dian Nuraini Melati ${ }^{1}$ \\ ${ }^{1}$ Pusat Teknologi Reduksi Risiko Bencana (PTRRB), Kedeputian TPSA - Badan Pengkajian dan \\ Penerapan Teknologi (BPPT) \\ Gedung Geostech, Lantai 1, Kompleks Puspiptek Serpong, Tangerang Selatan \\ e-mail: dian.nuraini@bppt.go.id
}

\begin{abstract}
There have been a lot of geospatial technologies implemented to support disaster management into a more effective way and achieve disaster risk reduction. One of these technologies is the use Volunteered Geographic Information (VGI). VGI refers to the volunteered activities by anyone to create geographic information. The recent development of VGI is obviously supported by the development technology itself such as social media, Global Positioning System (GPS) with acceptable accuracy. In addition, it is also supported by mostly unlimited cloud-based storage as well as smartphones. In the phenomena of natural disasters such as flood, landslide, earthquake, tsunami, and other phenomena, the need of geospatial data and the availability in timely manner becomes important and crucial at all disaster management aspects. The availability of geographic information is very much critical at the time the disaster occurs compared to normal situation. Therefore, VGI is necessary in supporting near real time information. In this case, it has a key role in disaster management particularly to reduce disaster risk.
\end{abstract}

Keywords: Geographic information, volunteer, disaster management

\begin{abstract}
ABSTRAK
Berbagai macam penerapan teknologi geospasial telah diimplementasikan dalam rangka mendukung kegiatan manajemen bencana menjadi lebih efektif dan dapat semaksimal mungkin mengurangi risiko bencana. Salah satu teknologi tersebut adalah dengan pemanfaatan Volunteered Geographic Information (VGI). VGI merujuk pada peran serta secara sukarela oleh berbagai pihak dalam menciptakan informasi geografis. Perkembangan VGI saat ini sangat didukung oleh perkembangan teknologi seperti media sosial, Global Positioning System (GPS) dengan akurasi posisi yang baik. Selain itu juga penyimpanan data hampir tidak terbatas yang berbasis cloud, dan juga telepon pintar (smartphone). Pada kejadian bencana alam seperti banjir, longsor, gempa bumi, tsunami maupun kejadian alam lainnya, kebutuhan data geospasial dan ketersediaannya yang memadai dan tepat waktu menjadi sangat penting dan krusial dalam segala aspek manajemen bencana. Kebutuhan informasi geografis menjadi sangat kritis pada saat terjadi bencana dibandingkan dengan kondisi normal dimana VGI menjadi sangat ideal untuk memenuhi kebutuhan informasi yang mendekati real time. Oleh karena itu, VGI memiliki peran yang penting dalam manajemen bencana terutama dalam pengurangan risiko bencana.
\end{abstract}

Kata kunci: Informasi geografi, sukarelawan, manajemen bencana 


\section{PENDAHULUAN}

\subsection{Latar Belakang}

Kejadian bencana alam banyak terjadi dengan skala besar baik di Indonesia maupun dunia internasional akhir-akhir ini. Sebagai contoh, gempa bumi dan tsunami di Indonesia dan Jepang, badai Katrina di Amerika, gempa bumi di Haiti, dan juga kebakaran hutan di Australia. Hal ini menyebabkan banyaknya kehilangan nyawa, kerusakan lingkungan, maupun kerugian ekonomi. Besar kecilnya nilai kehilangan tersebut sangat tergantung dengan kerentanan dari suatu populasi dalam menghadapi suatu bahaya atau dapat juga disebut sebagai ketangguhan (Velev and Zlateva, 2012). Hal ini berkaitan pula dengan nilai risiko terhadap suatu bencana yang merupakan fungsi dari bahaya dan kerentanan serta kapasitas. Risiko dari suatu kejadian bencana alam akan menjadi kecil pada suatu area dengan kerentanan rendah. Dengan meningkatkan kapasitas dalam suatu komunitas, tentu saja dapat mengurangi risiko suatu kejadian bencana. Pemanfaatan perkembangan teknologi yang ada saat ini merupakan suatu upaya dalam pengurangan risiko bencana.

Keberadaan Internet dan Geoweb 2.0 telah mendorong perkembangan yang sangat pesat terhadap fenomena dimana pengguna internet dapat berperan secara aktif dalam memberikan informasi (Elwood et al., 2012). Menurut Goodchild (2007b), Web 2.0 (O'Reilly, 2007) merupakan sarana online dua arah dimana pengguna dapat menambahkan informasi yang mereka miliki di internet sekaligus juga membaca informasi tersebut, sebagai contoh melalui wiki dan blog. Sedangkan geoweb didefinisikan sebagai pengembangan Web 2.0 yang berbasis geografis dimana kemampuannya dalam memberikan informasi data dan lokasi (Sieber et al., 2016). Pada geoweb, internet akan memberikan informasi dalam bentuk informasi geografis dan peta (Haklay et al., 2008), bertindak sebagai sarana untuk mengumpulkan, menganalisis, dan membagi data geografis (Gómez-Barrón et al., 2016). Contoh-contoh dari aktivitas ini adalah Wikimapia yang merupakan peta online dengan mengkombinasikan Google Map dan sistem wiki, dimana pengguna dapat menambahkan informasi pada setiap lokasi di muka bumi. Selain itu ada juga Flickr yang merupakan situs berbagi foto yang memiliki ratusan juta foto dengan georeferensi. OpenStreetMap (OSM) juga satu diantara aktivitas untuk membuat peta dunia dengan kontribusi dari berbagai pihak yang besifat sukarela.

Geoweb dapat dimanfaatkan oleh berbagai pihak dan dapat memfasilitasi segala kebutuhan terkait kolaborasi serta mengumpulkan informasi dari komunitas online yang bekerja secara sukarela untuk mencapai tujuan bersama dalam berbagi informasi (Gómez-Barrón et al., 2016). Dengan adanya informasi lokasi geografis, seluruh situs web terkait memiliki potensi sebagai sumber data geografis, informasi, bahkan ilmu pengetahuan (Elwood et al., 2012). Fenomena ini dikenal sebagai Volunteered Geographic Information (VGI) atau bisa juga disebut sebagai informasi geografis yang bersifat sukarela. VGI merujuk pada peran serta secara sukarela oleh berbagai pihak dalam menciptakan informasi geografis (Goodchild, 2007a). Perkembangan VGI saat ini sangat didukung oleh perkembangan teknologi seperti media sosial, Global Positioning System (GPS) dengan harga terjangkau serta mampu memberikan akurasi posisi yang baik. Selain itu juga penyimpanan data berbasis cloud dan telepon pintar (smartphone).

VGI telah diimplementasikan dalam berbagai aspek mulai dari tanggap darurat bencana (Zook et al., 2010), pemanfaatan sistem informasi geografis oleh publik secara umum, sampai dengan pemetaan dengan pendekatan urun daya (crowdsourcing). Pada kejadian bencana alam seperti banjir, longsor, gempa bumi, tsunami maupun kejadian alam lainnya, kebutuhan data geospasial dan ketersediaan data yang memadai dan tepat waktu menjadi sangat penting dan krusial dalam segala aspek manajemen bencana (Haworth and Bruce, 2015). Kebutuhan informasi geografis menjadi sangat kritis pada saat terjadi bencana dibandingkan dengan kondisi normal dimana VGI menjadi sangat ideal untuk memenuhi kebutuhan informasi yang mendekati real time (Goodchild and Glennon, 2010). VGI memiliki peran yang penting dalam manajemen bencana terutama dalam pengurangan risiko bencana. Manajemen bencana memiliki 4 siklus yang terdiri dari mitigasi, kesiapsiagaan (preparedness), tanggap darurat (response), dan pemulihan (recovery) (Horita et al., 2013).

Oleh karena itu, pengurangan dampak negatif akibat kejadian bencana membutuhkan pendekatan yang efektif pada keempat siklus tersebut (Zakour and Gillespie, 2013). Dalam konteks ini, kajian ini melakukan studi literatur mengenai peran $\mathrm{VGI}$ dalam manajemen bencana terutama dalam pengurangan risiko bencana. Hal ini terkait dengan konsep, implementasi, kualitas data VGI, dan peluang pengembangan di masa yang akan datang. 


\subsection{Tujuan Penelitian}

Penelitian dilakukan untuk mengkaji peran VGI dalam manajemen bencana khususnya dalam pengurangan risiko bencana. Terkait dengan tujuan tersebut, maka pengkajian penelitian meliputi konsep serta implementasi VGI dalam pengurangan risiko bencana,

\section{BAHAN DAN METODE}

\subsection{Bahan}

Dalam penelitian ini, bahan yang digunakan adalah artikel-artikel baik buku, laporan ataupun jurnal ilmiah terkait studi baik yang diterbitkan secara nasional maupun internasional. Hasil dari studi literatur terhadap artikel-artikel tersebut digunakan sebagai referensi dalam mengkaji peran VGI dalam pengurangan risiko bencana.

\subsection{Metode}

Penelitian dilakukan dengan langkah-langkah sebagai berikut:

1. Menelusuri literatur baik berupa buku, laporan, maupun artikel ilmiah dan melakukan studi pustaka terkait penelitian.

2. Membuat deskripsi mengenai konsep VGI dan pengurangan risiko bencana.

3. Membuat deskripsi mengenai implementasi VGI pada studi terkait

4. Membuat deskripsi mengenai kualitas data VGI. Dalam hal ini, dilakukan studi pustaka terhadap artikel terkait dan menuliskan isu-isu utama mengenai kualitas data yang banyak dijumpai dalam implementasi.

5. Melakukan deskripsi mengenai peluang pengembangan di masa yang akan datang. Atas penemuan isu-isu terkait di atas, maka dilakukan identifikasi mengenai peluang yang dapat dikembangkan dalam implementasi di masa yang akan datang.

\section{HASIL DAN PEMBAHASAN}

\subsection{VGI dan Pengurangan Risiko Bencana}

Sebelum abad 20, manajemen bencana hanya diperhatikan pada bahaya dari suatu bencana saja (Buckle, 1999). Namun demikian, saat ini cara berpikir tersebut mulai bergeser dengan memperhatikan juga pada manusia dan segala kerentenan yang ada sebagai faktor yang terpengaruh (Manyena et al., 2011). Bersamaan dengan ini, fokus dari manajemen bencana tidak hanya pada saat tanggap darurat tetapi juga memperhatikan pentingnya mitigasi dan kesempatan untuk meningkatkan partisipasi publik (Pearce, 2003). Kebijakan dalam manajemen bencana dengan memperhatikan kombinasi partisipasi publik dengan perencanaan manajemen bencana serta perencanaan komunitas akan menghasilakan suatu mitigasi bencana yang berkelanjutan (Pearce, 2003). Hal ini menjadi nyata tertuang dalam Hyogo Framework for Action 2005-2015, yang menghasilkan kebijakan yang diadopsi oleh 168 negara yang menekankan pada ketangguhan komunitas dalam mencapai manajemen bencana yang efektif (UNISDR, 2005). Selanjutnya diikuti pula dengan Sendai Framework untuk Reduksi Risiko Bencana 2015-2030 yang menekankan pada partisipasi komunitas dan manajemen risiko bencana (UNISDR, 2015). Mengingat pentingnya hal tersebut, manajemen kebencanaan telah bergeser dari model awal yang bersifat birokratis dari atas ke bawah menjadi suatu kolaborasi yang dinamis antara multi-organisasi, antar pemerintahan, dan kerja sama lintas sektoral (Waugh and Streib, 2006).

Peningkatan kebutuhan informasi terkait korban, pencarian informasi mengenai makanan, tempat tinggal sementara, dan logistik lainnya banyak terjadi saat terjadi bencana. Informasi tersebut tidak sekedar data kuantitas tetapi juga terkait dengan lokasi ataupun posisi geografis. Dalam hal ini, informasi geografis dari para sukarelawan yang terkomunikasikan dengan cepat menjadi sangat penting pada masa-masa krisis tersebut (Goodchild and Glennon, 2010). Kemunculan sosial media telah merubah cara orang dalam membuat dan menggunakan informasi pada saat-saat krisis (Ostermann and Spinsanti, 2011) seiring meningkatnya perkembangan teknologi komunikasi berbasis internet saat kejadian bencana (Velev and Zlateva, 2012). Sosial media memiliki peran penting dalam mendistribusikan informasi dimana orang tidak hanya dapat berbagi informasi tetapi juga dalam rangka mencari pertolongan.

Berbagai macam bentuk partisipasi dari komunitas tersebut telah membuka peluang bagi VGI pada manajemen bencana. Beberapa keuntungan dari pemanfaatan VGI adalah pertukaran informasi yang cepat serta keterhubungan antar komunitas dalam bertukar informasi, pengumpulan data yang mendekati real time tanpa batasan seperti teknologi geospasial lainnya dimana penggunaan data satelit yang terkendala dengan cuaca (TriglavČekada and Radovan, 2013), terkumpulnya data geospasial secara terbuka, dan kesempatan setiap individu secara sukarela dan berpartsipasi dari lokasi di luar area bencana. Namun demikian dibalik manfaat tersebut, studi terdahulu juga menyebutkan isu-isu terkait kredibilitas dan kualitas data serta keamanan 
dari informasi dan sukarelawan (Flanagin and Metzger, 2008).

\subsection{Implementasi Pemanfaatan VGI dalam Pengurangan Risiko Bencana}

Berikut di bawah ini akan disampaikan contoh-contoh implementasi pemanfaatan VGI dalam pengurangan risiko bencana pada jenis bencana yang berbeda.

\section{a. Banjir}

Degrossi et al. (2014) menciptakan suatu platform yang dikenal dengan nama Flood Citizen Observatory (FCO). Pendekatan yang dilakukan adalah dengan memanfaatkan informasi yang dikumpulkan dari para sukarelawan untuk manajemen risiko banjir di Brazil. Informasi yang dikumpulkan meliputi area banjir dan tinggi muka air sungai, Informasi ini digunakan sebagai masukan dalam pengambilan keputusan selanjutnya. Platform FCO ini berbasis platform urun daya yang dikenal dengan nama Usahidi yang telah banyak digunakan oleh badan-badan penanggulangan bencana dan juga masyarakat untuk memberikan informasi terkait manajemen risiko bencana (de Albuquerque et al., 2016).

Melalui platform FCO (Gambar 1), setiap pengguna memberikan informasi hasil pengamatan terkait parameter penting dalam manajemen risiko banjir di daerahnya. Menurut Degrossi et al. (2014), hasil pengamatan beberapa parameter antara lain hasil pengukuran tinggi muka air, dimana pada titik tertentu di sungai telah dibuat suatu batas-batas pengukuran, sehingga masyarakat dengan mudah dapat membaca. Sedangkan pada lokasi yang tidak dapat ditemui batas-batas pengukuran tersebut, maka dilakukan pendekatan dengan cara yang lebih mudah. Pendekatan tersebut dillakukan dengan memberikan informasi tingkatan level yaitu rendah, normal, tinggi, dan meluap.

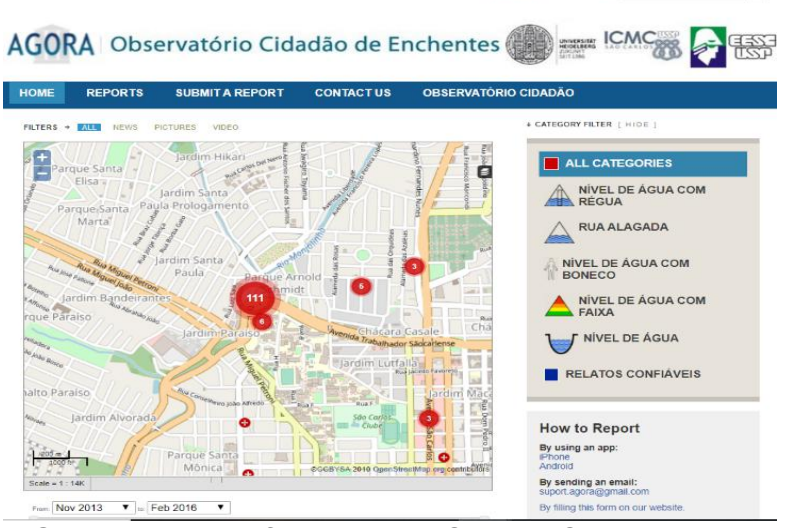

Gambar 1. Platform Flood Citizen Observatory untuk Manajemen Risiko Banjir (Sumber:

Degrossi et al., 2014)
Sukarelawan dapat mengirimkan laporan melalui aplikasi telepon seluler maupun web site. Dalam rangka mengurangi ketidakpastian (uncertainty) dan menjaga kredibilitas hasil pelaporan, maka dilakukan pengecekan dan verifikasi terlebih dahulu oleh administrator. Tujuan dari langkah ini adalah untuk mengurangi kesalahan dan ketidakakurasian informasi. Sehingga hasil yang disebarluaskan kepada masyarakat adalah informasi yang akurat. Dengan demikian, setiap laporan yang masuk akan selalu dilakukan verifikasi oleh adminstrator sebelum dipubikasikan pada platform.

\section{b. Kebakaran hutan}

Pemanfaatan teknologi VGI pernah diimplementasikan pada kasus kebakaran hutan di Santa Barbara, California, Amerika (Goodchild and Glennon, 2010). Santa Barbara terletak di sebelah selatan alam liar dan banyak rumah yang dibangun berdekatan dengan semak belukar. Semak belukar yang ada merupakan jenis yang mengandung minyak yang membuat spesies ini mudah terbakar. Pada bulan Juli 2008 kebakaran terjadi di bukit yang terletak di sebelah utara kota, serta mengancam banyak perumahan dan area kota. Durasi yang pendek antara terjadinya kebakaran dan ancaman yang parah membutuhkan informasi yang cepat yang dapat disediakan dengan teknologi VGI.

Pada umumnya, masyarakat hanya bergantung pada institusi formal yang akan memberikan informasi dan perintah evakuasi. Namun demikian, dengan implementasi VGI, sukarelawan dapat membuat dan menyebarluaskan informasi geografis secara lebih cepat. Sementara itu, institusi formal sering kali terkendala dengan sumber daya yang terbatas dan juga memerlukan waktu tunggu untuk verifikasi informasi. Berbeda dengan pemanfaatan teknologi saat ini yang mendukung penerapan VGI, seperti kamera digital, GPS, peta digital. Hal tersebut memungkingkan para sukarelawan untuk berbagi informasi.

Perkembangan pemanfaatan VGI ini sangat berperan dalam mengurangi risiko bencana yang terjadi di bulan Mei 2009. Dimana kebakaran semak belukar terjadi dalam dua hari (Goodchild and Glennon, 2010). Banyak masyarakat dan komunitas yang secara sukarela membuat situs dengan peta informasi, melakukan sintesis, dan memberikan informasi secara konstan. Sebagai contoh, parameter kebakaran selalu diperbaharui dan dilaporkan kepada masyarakat. Salah satu situs yang banyak dikunjungi adalah seperti pada Gambar 2, dimana mampu memberikan lokasi kebakaran, instruksi evakuasi, lokasi-lokasi penampungan, serta banyak informasi lainnya. 


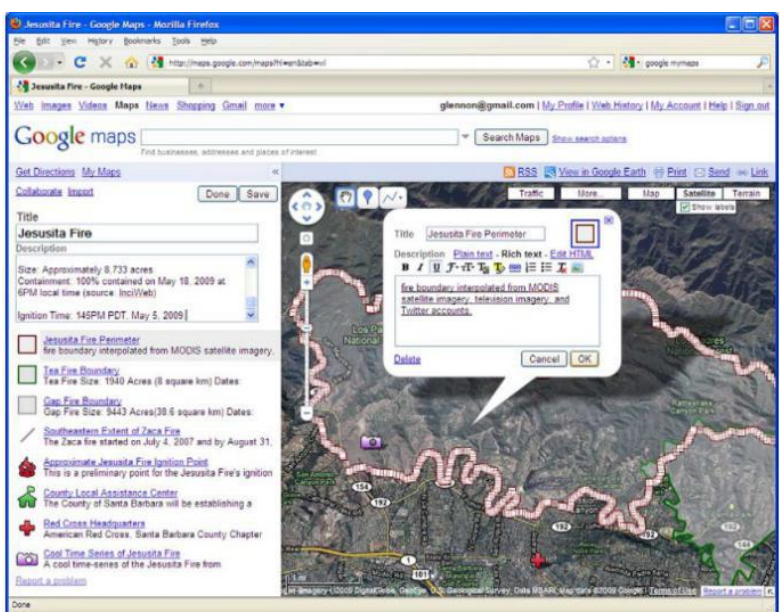

Gambar 2. Contoh Sistem VGI terkait Kebakaran Lahan (Sumber: Goodchild and Glennon, 2010)

\section{c. Gempa bumi}

VGI juga memiliki peranan penting pada saat terjadi bencana gempa bumi di Haiti di tahun 2010. Di negara ini, data mengenai gambaran umum negara ini sebelum terjadi gempa bumi membuat seperti peta jalan, lokasi-lokasi asset yang penting sangat terbatas (Zook et al., 2010). Hal ini tentu saja mempersulit aktivitas tanggap darurat pada saat terjadi gempa bumi. Untuk memenuhi kebutuhan ini, komunitas sukarelawan, organisasi mulai berkontribusi melalui fasilitas online seperti blog, email, maupun twitter. Sebagai contoh, komunitas sukarelawan OpenStreetMap (OSM) yang melakukan pemetaan jalan, infrastruktur maupun bangunanbangunan lain menggunakan data citra satelit yang telah banyak tersedia secara gratis. Selanjutnya, hasil dari pemetaan ini diunggah ke basis data OSM dan kemudian dilengkapi dengan survei lapangan oleh sukarelawan di Haiti yang dilengkapi dengan GPS.

Selanjutnya ada juga pemanfaatan platform Ushahidi (Okolloh, 2009). Pengguna Ushahidi dapat mengirimkan SMS, MMS, ataupun media daring lainnya. Selanjutnya informasi ini akan dimasukkan di area geografis tertentu pada suatu peta interaktif. Sukarelawan juga memantau cuitan di twitter yang menggunakan hashtag \#Haiti. Dengan menggunakan fasilitas Ushahidi ini, penyampaian bantuan menjadi lebih efektif karena informasi posisi geografis dan koordinat yang tersedia pada basis data. Gambar di bawah ini menunjukkan sistem yang bekerja dalam pelaporan mengenai penemuan korban menggunakan platform Ushahidi.

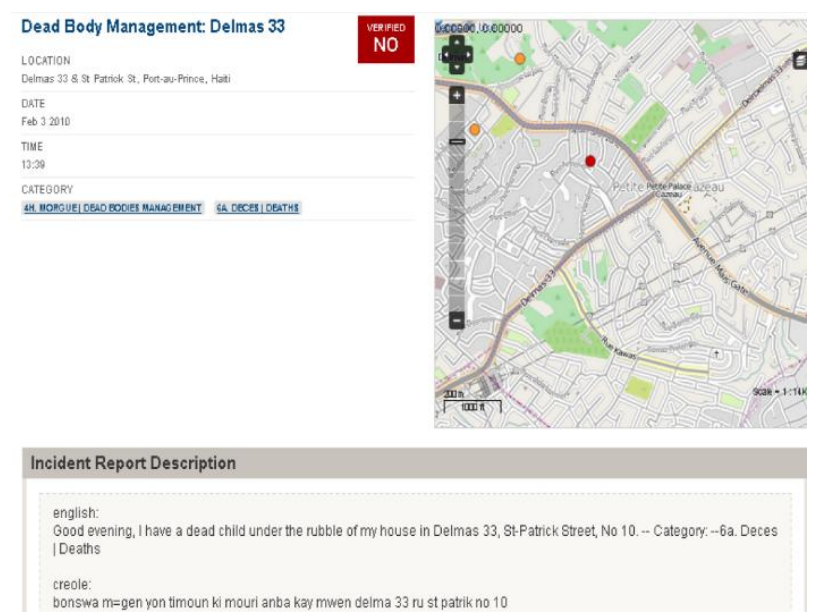

Gambar 3. Sistem Pelaporan Menggunakan

Platform Ushahidi (Sumber: Zook et al., 2010)

\subsection{Kualitas Data VGI dalam Pengurangan Risiko Bencana}

Isu yang sering muncul terkait pemanfaatan VGI adalah terkait dengan kredibilitas, reliabilitas, dan kualitas VGI (Flanagin and Metzger, 2008). VGI dapat mendukung dalam percepatan menuju Smart City, yaitu suatu wilayah kota dengan integrasi teknologi informasi dan juga komunikasi dalam segala aktivitas pelayanan publik, bila data yang diberikan cukup kredibel untuk dipercayai. Oleh karenanya, kredibilitas data menjadi hal yang sangat diperhatikan dalam pemanfaatan untuk manajemen bencana. Elwood (2008) menyebutkan bahwa informasi yang dihasilkan dari VGI memiliki kredibilitas dan reliabilitasi yang kurang dapat dipercaya karena bukan diproduksi oleh para ahli. Namun demikian, apabila persyaratan pada VGI dibuat cukup ketat baik dalam hal spesifikasi, presisi, lingkup spasial, siklus pembaruan, maupun susunan metadata maka hal ini akan menurunkan minat sukarelawan (Antoniou et al., 2017).

Di sisi lain, perlu diketahui bahwa terkadang VGI juga tidak kalah baik kualitasnya dengan data-data formal dari suatu institusi dalam hal hasil pemetaan yang diperoleh (OlteanuRaimond et al., 2017). Pada dasarnya, informasi geografi tidak lepas dengan kesalahan pengukuran, tingkat kedetilan yang kurang akurat ketidakjelasan definisi, dan banyak sumbersumber ketidakpastian lainnya (Zhang and Goodchild, 2002). Dengan keterbatasan kualitas data geospasial tidak memungkinkan untuk dapat merepresentasikan segala aspek geografi dengan sempurna. Pengguna perlu melakukan investigasi secara sistematis mengenai data-data yang tersedia, apakah keakuratan sudah mencukupi untuk suatu tujuan penggunaan (Elwood et al., 2012).

Secara umum, data yang dikeluarkan oleh institusi formal akan melalui prosedur yang lengkap untuk menjamin kredibilitas dan 
reliabilitas data. Misalnya dengan menentukan spesifikasi tertentu terkait basis data geografis yang sesuai standar, melaksanakan pengkajian kualitas secara periodik, dan kemudian mempublikasikan standar kualitas suatu data. Namun demikian, hal ini berbeda dengan data VGI. Data VGI diperoleh dari sejumlah sukarelawan. Dalam hal ini pengecekan data tidak lagi dilakukan oleh para ahli akan tetapi oleh sejumlah orang lain yang tidak saling mengenal (Elwood et al., 2012). Hal ini dapat juga dilihat dengan pemanfaatan informasi menggunakan Wikipedia. Wikipedia memberikan bukti bahwa peran serta sukarelawan dalam berbagi informasi sangat efektif. Setiap orang memiliki kesempatan untuk memberikan laporan untuk mengurangi ketidakakurasian informasi yang dibaca (Giles, 2005). Begitu juga dengan pemanfaatan platform OpenStreetMap dimana setiap pengguna memiliki kesempatan untuk memperbaiki sehingga dapat meningkatkan kualitas data.

Dengan demikian, pemanfaatan VGI dalam mengurangi risiko bencana masih memiliki peran yang penting. Sebagai contoh, dapat kita lihat pada kasus kebakaran lahan di Santara Barbara seperti yang digambarkan pada sub-bagian sebelumnya. Dari kasus tersebut, tidak ada yang menjamin bahwa informasi yang diberikan oleh sukarelawan mengenai status kebakaran tersebut tidak akurat ataupun kualitas yang tidak bagus. Dalam situasi yang mendesak seperti ini, pengambil keputusan harus membuat pilihan antara mengambil aksi yang cepat dengan data yang masih dipertanyakan ataukah menunggu data yang lebih baik. Data-data formal biasanya tidak cepat tersampaikan karena memerlukan verifikasi data, bahkan terkadang terlambat dalam menit maupun jam dibandingkan dengan data dari sukarelawan. Sementara itu, banyak aksi yang diperlukan dalam situasi ini terkait evakuasi walaupun akan ada risiko bahwa informasi tersebut menjadi tidak benar. Namun demikian, keterlambatan aksi sebagai akibat informasi yang lamban akan membawa risiko yang lebih tinggi terhadap ancaman korban jiwa.

\subsection{Tantangan Pemanfaatan VGI}

Sebagaimana dijelaskan sebelumnya bahwa kualitas data VGI menjadi salah satu isu dalam pemanfaatannya, maka penelitian terkait dengan evaluasi kualitas data VGI akan dapat menjadi peluang penelitian di masa yang akan datang. Sebuah metodologi terkait evaluasi data kualitas dapat berupa spesifikasi ISO (Antoniou, 2017). Selain itu dapat juga ditambahkan suatu perangkat (tool) tambahan sebagai evaluasi (Antoniou and Skopeliti, 2015). Apabila hal ini tidak dikembangkan, maka dapat menurunkan minat pengguna dalam pemanfaatan data VGI.
VGI merupakan kombinasi multidisiplin, baik itu sosial, ekonomi, maupun teknologi terutama terkait teknologi geospasial. Informasi yang diperoleh merupakan gambaran kejadian di suatu lokasi berdasarkan pemantauan masyarakat. Oleh karena itu, unsur ketidakpastian, bias maupun noise perlu diminimalisir. Bagaimana suatu metodologi ataupun pemodelan dalam mengurangi unsur ketidakpastian tersebut merupakan tantangan selanjutnya.

Tantangan pemanfaatan VGI di masa yang akan datang juga terkait dengan harmonisasi data. Dimana saat ini perkembangan big data semakin pesat dan mudah untuk diakses. Diharapkan untuk dapat ditemukan suatu metode yang dapat memberikan informasi hasil rerata dari sekian banyak informasi yang masuk, dan juga memberikan suatu kajian awal mengenai kualitas data secara otomatis (Kuhn, 2007; Antoniou et al., 2017).

Menurut Haworth and Bruce (2015), bahwa diperlukannya penelitian tidak hanya mengenai validasi data akan tetapi juga suatu laporan ringkasan. Verifikasi data dan sistem pelaporan yang berupa ringkasan dapat membantu dalam manajemen kebencanaan sekaligus juga dapat memberikan informasi mengenai kualitas data dan hal-hal terkait manajamen dalam suatu bencana. Dengan manfaat-manfaat yang dapat dilihat dalam peggunaan VGI, hal ini tentu saja dapat mendorong penggunaannya di masa yang akan datang. Oleh karena itu, penelitian terkait dengan kajian kualitas data VGI perlu menjadi prioritas utama mengingat begitu tingginya potensi pemanfaatan teknologi VGI ini dalam manajemen bencana.

$\mathrm{Di}$ Indonesia, dapat dilihat bahwa masyarakat secara mandiri sudah mulai memanfaatkan kecanggihan teknologi untuk mengumpulkan informasi berbasis geospasial. Misalnya melalui sosial media memberikan informasi terkait kejadian suatu bencana dan memberikan informasi geografisnya pula. Contoh nyata adalah pemanfaatan Twitter dalam memberikan informasi lokasi evakuasi pada saat terjadi bencana banjir di Jakarta (Kusumo et al., 2017). Penulis meyakini bahwa aktivitas ini akan semakin meningkat di masa yang akan datang.

\section{KESIMPULAN}

Dapat dilihat dari berbagai contoh implementasi pemanfaatan $\mathrm{VGI}$ tersebut sebelumnya dimana informasi VGI merupakan hasil partisipasi masyarakat dan para sukarelawan dalam memberikan informasi mengenai suatu fenomena di lingkungannya secara cepat dan real time. Hal ini tentu saja dapat memberikan masukan bagi pengambil keputusan dalam bergerak mengambil langkahlangkah nyata terkait pengurangan risiko 
bencana. Dibandingkan cara tradisional, dimana harus menunggu data formal yang dikeluarkan oleh institusi terkait.

Namun demikian, perlunya suatu kajian mengenai informasi tambahan kualitas data VGI menjadikan suatu tantangan di masa yang akan datang. Hal ini memberikan banyak kesempatan untuk penelitian lebih lanjut mengenai suatu metodologi untuk dapat memperoleh informasi kualitas data VGI serta kemampuan dalam memberikan suatu ringkasan dari sekian banyak informasi yang masuk.

\section{PERSANTUNAN}

Penulis mengucapkan terima kasih kepada dewan redaksi serta reviewer atas masukan yang diberikan sehingga artikel ini dapat diterbitkan. Dengan ini, penulis menyampaikan bahwa artikel ini tidak menimbulkan potensi konflik kepentingan.

\section{DAFTAR PUSTAKA}

Antoniou, V., and A. Skopeliti. 2015. Measures and indicators of VGI quality: An overview, in: ISPRS Annals of the Photogrammetry, Remote Sensing and Spatial Information Sciences. Presented at the ISPRS Geospatial Week 2015, ISPRS Annals, La Grande Motte, France, pp. 345-351.

Antoniou, V., L. See, G. Foody, C.C. Fonte, P. Mooney, L. Bastin, S. Fritz, H-Y. Liu, A-M. Olteanu-Raimond, and R. Vatseva, R. 2017. The Future of VGI. In: Foody, G, See, L, Fritz, S, Mooney, P, Olteanu-Raimond, A-M, Fonte, C C and Antoniou, V. (eds.) Mapping and the Citizen Sensor. Pp. 377-390. London: Ubiquity Press. DOI: https://doi.org/10.5334/bbf.p. License: CCBY 4.0

Buckle, P. 1999. Re-defining community and vulnerability in the context of emergency management. The Australian Journal of Emergency Management, 13(4): 21.

de Albuquerque, J. P., M. Eckle, B. Herfort, and A. Zipf. 2016. Crowdsourcing geographic information for disaster management and improving urban resilience: an overview of recent developments and lessons learned. European handbook of crowdsourced geographic information, 309321.

Degrossi, L. C., J.P. de Albuquerque, M.C. Fava, and E.M. Mendiondo. 2014. Flood Citizen Observatory: a crowdsourcing-based approach for flood risk management in Brazil. In SEKE (pp. 570-575).
Elwood, S. 2008. Volunteered geographic information: future research directions motivated by critical, participatory,and feminist GIS. GeoJournal, 72(3-4): 173-183.

Elwood, S., M. F. Goodchild, and D.Z. Sui. 2012. Researching volunteered geographic information: Spatial data, geographic research, and new social practice. Annals of the association of American geographers, 102(3): 571-590.

Flanagin, A. J., and M.J. Metzger. 2008. The credibility of volunteered geographic information. GeoJournal, 72(3-4): 137-148.

Giles, J. 2005. Special report: internet encyclopaedias go head to head. Nature 438: 900-901.

Gómez-Barrón, J. P., M. Á. Manso-Callejo, R. Alcarria, and T. Iturrioz. 2016. Volunteered Geographic Information system design: Project and participation guidelines. ISPRS International Journal of GeoInformation, 5(7): 108.

Goodchild, M. F. 2007a. Citizens as sensors: The world ofvolunteered geography. GeoJournal 69 (4): 211-21.

Goodchild, M. F. 2007b. Citizens as voluntary sensors: spatial data infrastructure in the world of Web 2.0. International journal of spatial data infrastructures research, 2(2): 24-32.

Goodchild, M. F., and J.A. Glennon. 2010. Crowdsourcing geographic information for disaster response: a research frontier. International Journal of Digital Earth, 3(3): 31-241.

Haklay, M., A. Singleton, and C. Parker. 2008. Web mapping 2.0: The neogeography of the GeoWeb. Geography Compass 2.6: 20112039.

Haworth, B., and E. Bruce. 2015. A review of volunteered geographic information for disaster management. Geography Compass, 9(5): 237-250.

Horita, F. E. A., L.C. Degrossi, L.F.F.G. Assis, A. Zipf, and J.P.D. Albuquerque. 2013. The use of volunteered geographic information and crowdsourcing in disaster management: a systematic literature review. In Proceedings.

Kuhn, W. 2007. Volunteered geographic information and GIScience. Position Paper for the NCGIA and Vespucci Workshop on Volunteered Geographic Information. Santa Barbara, CA, 13-14 Dec 2007.

Kusumo, A. N. L., D. Reckien, and J. Verplanke. 2017. Utilising volunteered geographic information to assess resident's flood 
evacuation shelters. Case study: Jakarta. Applied geography, 88: 174-185.

Manyena, B., G. O'Brien, P. O'Keefe, and J. Rose. 2011. Disaster resilience: a bounce back or bounce forward ability?. Local Environment: The International Journal of Justice and Sustainability, 16(5): 417-424.

Okolloh, O. 2009. Ushahidi, or 'testimony': Web 2.0 tools for crowdsourcing crisis information. Participatory learning and action, 59(1): 5-70.

Olteanu-Raimond, A.-M., G. Hart, G. Foody, G. Touya, T. Kellenberger, and D. Demetriou, 2017. The scale of VGI in map production: A perspective of European National Mapping Agencies. Transactions in GIS 21: 74-90.

O'Reilly, T. 2007. What Is Web 2.0: Design Patterns and Business Models for the Next Generation of Software. International Journal of Digital Economics No. 65 (March 2007): 17-37.

Ostermann, F. O., and L. Spinsanti. 2011. A conceptual workflow for automatically assessing the quality of volunteered geographic information for crisis management. In Proceedings of AGILE, 2011: 1-6.

Pearce, L. 2003. Disaster management and community planning, and public participation: how to achieve sustainable hazard mitigation. Natural Hazards, 28(2-3): 211228.

Sieber, R. E., P.J. Robinson, P.A. Johnson, and J.M. Corbett. 2016. Doing public participation on the geospatial web. Annals of the American Association of Geographers, 106(5): 1030-1046.

Triglav-Čekada, M., and D. Radovan. 2013. Using volunteered geographic information to map the November 2012 floods in Slovenia. Natural Hazards and Earth System Sciences Discussion 1: 2859-2881.

UNISDR. 2005. Building the resilience of nations and communities to disasters: Hyogo Frameworkfor Action 2005-2015. [terhubung berkala] http://www.unisdr.org/2005/wcdr/intergover/ official-doc/L-docs/Hyogo-frameworkforaction-english.pdf [18 Maret 2020].

UNISDR. 2015. Sendai framework for disaster risk reduction 2015-2030.

[terhubung berkala] http://www.preventionweb.net/files/43291_s endaiframeworkfordrren.pdf [20 Maret 2020].

Velev, D., and P. Zlateva. 2012. Use of social media in natural disaster management. Intl.
Proc. of Economic Development and Research, 39: 41-45.

Waugh Jr, W. L., and G. Streib. 2006. Collaboration and leadership for effective emergency management. Public administration review, 66: 131-140.

Zakour, M. J., and D.F. Gillespie. 2013. Community disaster vulnerability. Theory, Research, and Practice.

Zhang, J., and M.F. Goodchild. 2002. Uncertainty in geographical information. CRC press.

Zook, M., M. Graham, T. Shelton, and S. Gorman. 2010. Volunteered Geographic Information and Crowdsourcing Disaster Relief: A Case Study of the Haitian Earthquake," World Medical \& Health Policy, 2(2): Article 2. 